\title{
URGENSI KEBIJAKAN REKLAMASI PANTAI UTARA DKI JAKARTA DAN DAMPAK YANG DITIMBULKAN
}

\author{
Urgensi Reclamation Policy of the DKI Jakarta's North Coast and \\ Impact Imposed
}

Insan Harapan Harahap ${ }^{1}$, Nana Suryana ${ }^{1}$

Diterima: 11 Juni 2018 Disetujui: 29 Mei 2019

\begin{abstract}
Abstrak; Perdebatan terkait kebijakan reklamasi Pantai Utara DKI Jakarta memang seperti tidak ada ujungnya. Kebijakan reklamasi ini dianggap tidak sesuai dengan prosedur yang berlaku, kebijakan tersebut menjadi arena pertarungan antar penguasa dan pengusaha, Selain itu kasus suap dan korupsi hadir menyelimuti kebijakan reklamasi Pantai Utara DKI Jakarta. Atas dasar itu, penulis mencoba untuk meneliti tentang bagaimana urgensi kebijakan reklamasi Pantai Utara DKI Jakarta dan dampak yang akan ditimbulkan, selain itu penelitian ini mencoba untuk menjelaskan siapa saja aktor yang memiliki kepentingan dalam proyek reklamasi ini. Penelitian ini bersifat deskriptif, dimana data dan informasi yang dipergunakan dalam penelitian ini meliputi studi dokumen dan wawancara kepada lembaga terkait yang memiliki relasi dengan kebijakan reklamasi Pantai Utara DKI Jakarta. Hasil penelitian ini menyimpulkan bahwa proyek reklamasi Pantai Utara DKI Jakarta menyebabkan dampak negatif dan positif. Proyek reklamasi ini bukan hanya dapat memecahkan permasalahan yang ada, malah menciptakan permasalahan yang baru terkait dengan dampak buruk terhadap lingkungan. Selain itu, proyek reklamasi mengganggu keberlangsungan penghidupan para nelayan disekitaran Pantai Utara DKI Jakarta.
\end{abstract}

Kata Kunci: Kebijakan, Reklamasi, Pengembagan Tata Kota.

Abstract; Controversy related to the reclamation policy of the DKI Jakarta's North Coast is endless. Its reclamation policy is reputed inappropriate with the prevail procedure, its policy becomes a fighting zone between authority and entrepreneur, beside them bribe cases and corruption was shown covering its reclamation policy of DKI Jakarta's North Coast. Therefore, writer tried to explain whose the actor belongs to its reclamation project. This research will be descriptive, which the data and information's used in this research contains of documentation studies and interview with the related institution whose has relation with the reclamation project of DKI Jakarta's North Coast. The result of this research will be concluded that the reclamation project of DKI Jakarta's North Coast has a positive and negative impact. This reclamation project can not only solve the existing problems, instead creating new problems associated with adverse environmental impacts. In addition, the reclamation project disrupted the livelihood of fishermen in the North Coastal area of DKI Jakarta.

Keywords: Policy, Reclamation, Development of Urban Space.

\footnotetext{
${ }^{1}$ Program Studi S1 Ilmu Politik Universitas Bakrie
} 


\section{PENDAHULUAN}

Kebijakan reklamasi Pantai Utara DKI Jakarta merupakan kebijakan yang syarat dengan kontroversi, ditambah adanya tindak pidana korupsi oleh Ketua Komisi Pembangunan DPRD DKI Jakarta Muhammad Sanusi, Presdir PT APL Ariesman Widjaja, dan karyawan PT APL Trinanda Prihantoro, dimana ketiganya ditetapkan sebagai tersangka usai KPK melakukan operasi tangkap tangan. Sanusi diketahui menerima uang Rp 2 miliar dari Ariesman dan Trinanda untuk meluluskan proyek reklamasi Pantai Utara DKI Jakarta dalam pembahasan rancangan peraturan daerah (Rapperda). Kasus korupsi tersebut termasuk dalam grand corruption (korupsi besar yang berkaitan dengan kebijakan publik di DKI Jakarta. Padahal pengambil kebijakan itu harus memiliki orientasi pada kepentingan publik yang kuat. IrfanIslamy dalam (Nurani, 2017) menyebutnya dengan "semangat kepublikan" (the spirit of publicness).

Selain adanya tindakan korupsi yang terjadi pada sekitaran kebijakan reklamasi Pantai Utara DKI Jakarta, Pengadilan Tata Usaha Negara (PTUN) memutuskan mencabut ijin reklamasi dari Keputusan Gubernur Provinsi DKI Jakarta No. 2268 tahun 2015. Dalam perkara tersebut, secara garis besar majelis hakim mempertimbangkan ada cacat dalam penerbitan izin. Cacat itu antara lain izin reklamasi tidak diumumkan dan tidak melibatkan warga terdampak dalam kajian AMDAL (Gual 2017). Penerbitan ijin tersebut dianggap mencederai demokrasi, yang seharusnya kebijakan publik harus bersinggungan erat dengan konsep demokrasi (Muchsin \& Putra, 2002). Apabila kebijakan tidak bersingungan dengan konsep demokrasi, biasanya disebut dengan istilah iron cage atau ada yang menyebutnya sebagai iron triangle (Jordan:1998, Smith:1990, dalam (Putra, 2005)).

Kasus reklamasi tersebut dianggap mencederai nilai-nilai kebijakan publik yang telah diamanatkan konstitusi demi pencapaian kesejahteraan untuk masyarakat secara umum. Harold Laswell dan Kaplan dalam (Howlett , Michael; Ramesh, 1995) mendefinisikan kebijakan publik sebagai suatu program yang diproyeksikan dengan tujuan-tujuan, nilainilai, dan praktik-praktik tertentu (a projected of goals, values, and practices). Sedangkan, menurut Laswell yang dikutif oleh (Fischer, Miller, \& Sidney, 2007) model proses kebijakan publik dibedakan menjadi beberapa tahapan, yaitu: " $A$ model of the policy process comprised of seven stages: intelligence, promotion, prescription, invocation, application, termination, and appraisal. While this sequence of stages has been contested (in particular that termination comes before appraisal), the model itself has been highly successful as a basic framework for the field of policy studies and became the starting point of a variety of typologies of the policy process". Sejalan dengan itu, kalau dilihat dari maksud reklamasi pada awalnya, merupakan salah satu bentuk upaya memecahkan permasalahan kekurangan lahan dan memperbaiki tata ruang kota DKI Jakarta.

Provinsi DKI Jakarta terbagi menjadi 5 (lima) wilayah Kota Administrasi dan satu Kabupaten Administratif, yakni: Kota Administrasi Jakarta Pusat dengan luas 47,90 km2, Jakarta Utara dengan luas 142,20 km2, Jakarta Barat dengan luas 126,15 km2, Jakarta Selatan dengan luas 145,73 km2, dan Jakarta Timur dengan luas 187,73 km2, serta Kabupaten Administratif Kepulauan Seribu dengan luas 11,81 km2. Di sebelah utara membentang pantai sepanjang $35 \mathrm{~km}$, yang menjadi tempat bermuaranya 13 buah sungai dan 2 buah kanal. Di sebelah Selatan dan Timur berbatasan dengan Kota Depok, Kabupaten Bogor, Kota Bekasi dan Kabupaten Bekasi, sebelah barat dengan Kota Tangerang dan Kabupaten Tangerang, serta di sebelah utara dengan Laut Jawa (Perda DKI Jakarta, 2009).

Jakarta berkembang menjadi kota metropolitan dengan pertumbuhan pesat. Jakarta sebagai pusat perekonomian, bisnis, keuangan, industri perdagangan, bahkan sebagai pusat kegiatan politik, sosial, budaya, dan seni. Jakarta juga menjadi pusat berbagai kegiatan internasional (pullfactors). Dominasi (urban primacy) pertumbuhan Jakarta ditunjukkan 
secara sangat nyata dengan berkembangnya Jakarta sebagai magnet bagi wilayah sekitarnya (Kuncoro, 2012).

Pesatnya pertumbuhan DKI Jakarta menyisakan eksternalitas dinamis yang seharusnya dapat dicermati sejak awal sehingga dapat diantisipasi. Pembangunan pusatpusat perbelanjaan di Jakarta dengan dalih memenuhi kebutuhan konsumen, sebenarnya telah melebihi batas ideal dari jumlah penduduknya. Pembangunan apartemen dan hunian mewah di berbagai lokasi menjadi persoalan tersendiri. Belum lagi banyaknya daya dukung sektor informal yang memadati ruang-ruang publik. Hal inilah yang menyebabkan terjadinya perubahan tata ruang kota. Daerah resapan air, ruang hijau, dan fungsi taman kota berubah menjadi mal dan apartemen. Sementara bantaran sungai, pinggiran kali, dan daerah cekungan berubah menjadi perkampungan kumuh dan padat penduduknya (Adisasmita, 2014).

Walaupun pertumbuhan ekonomi yang cukup tinggi, namun kondisi DKI Jakarta terlihat seperti koin yang memiliki dua sisi yang berbeda, yaitu DKI Jakarta sebagai Ibukota Negara, tentunya berdampak kepada pesatnya pertumbuhan ekonomi dan infrastruktur yang memadai. Kemudian, sisi lainnya adalah Pemerintah Provinsi DKI Jakarta mendapatkan banyak permasalahan yang kompleks, seperti pertumbuhan penduduk yang kemudian semakin pesat, sehingga kurangnya ketersediaan lahan.

Dengan melihat persoalan Jakarta, di mana setiap tahunnya mengalami pertumbuhan penduduk, maka luas daratan ibukota Jakarta dipandang sudah tidak mencukupi sebagai tempat penyediaan ruang bagi kawasan pemukiman elit, tempat wisata, kawasan bisnis dan lain sebagainya. Melihat keterbatasan untuk pengembangan tata ruang dan wilayah, Pemerintah Provinsi DKI Jakarta dan Pemerintah Pusat mendapatkan solusi untuk dapat melakukan reklamasi pada pesisir Pantai Utara Jakarta. Berdasarkan kompleksitas permasalahan lahan yang terjadi di Jakarta, Pemerintah pusat memberikan wewenang terhadap DKI Jakarta untuk melakukan reklamasi yang ada di kawasan Pantai Utara. Kebijakan ini dibuat dan diimplementasikan sebagai sebuah bentuk tindakan responsif yang dilakukan oleh pemerintah Provinsi DKI Jakarta.

Kawasan Pantai Utara DKI Jakarta merupakan kawasan yang memiliki nilai strategis bagi wilayah Provinsi DKI Jakarta. Kawasan perairan dan pantai sepanjang $\pm 32 \mathrm{~km}$ di Teluk Jakarta tersebut merupakan gerbang DKI Jakarta dalam lingkup nasional, regional, dan internasional. Oleh karenanya, dalam Peraturan Daerah Provinsi DKI Jakarta No. 1 Tahun 2012 tentang RTRW Jakarta 2030, Kawasan Pantai Utara (Pantura) DKI Jakarta ditetapkan sebagai Kawasan Strategis Provinsi DKI Jakarta. Pengembangan Kawasan Pantura sebagai kawasan yang bernilai strategis telah diindikasikan sejak perencanaan tata ruang pada masa yang lampau sebagaimana kategorinya sebagai Kawasan Andalan dari sudut pandang ekonomi dan perkembangan kota berdasarkan Keppres No. 17 Tahun 1994, penataan ruang melalui reklamasi secara terpadu dengan daratan pantai yang ada berdasarkan Keppres No. 52 Tahun 1995 tentang Reklamasi Pantai Utara Jakarta, serta Perda DKI Jakarta No. 8 Tahun 1995 tentang Penyelenggaraan Reklamasi dan Rencana Tata Ruang Kawasan Pantura DKI Jakarta.

Kebijakan reklamasi yang telah diinisiasi oleh pemerintah pusat, kemudian diserahkan kepada Pemerintah Daerah DKI Jakarta sebagai Ibukota Negara yang memiliki wewenang dan tugas khusus untuk menjalankannya, dengan harapan perencanaan pembangunan nasional ataupun daerah mengenai reklamasi tersebut dapat terealisasi serta memberikan dan menambah fungsi lahan DKI Jakarta sekaligus Ibukota negara.

Proyek pengembangan Kawasan Pantura Jakarta sebenarnya bukan merupakan gagasan baru yang lahir setelah Keppres No. 52 tahun 1995. Keppres No.52 Tahun 1995 telah memberikan kewenangan dan tanggung jawab kepada Gubernur DKI Jakarta untuk menyelenggarakan reklamasi Kawasan Pantura Jakarta, yang ditindaklanjuti oleh Perda DKI No. 8 Tahun 1995 tentang Penyelenggaraan Reklamasi dan Rencana Tata Ruang Kawasan 
Pantura Jakarta. Sementara itu Perda DKI Jakarta No. 6 Tahun 1999 tentang RTRW Jakarta 2010 dan Peraturan Gubernur No. 121 Tahun 2012 juga ikut memberikan panduan kebijakan terhadap penyelenggaraan reklamasi Kawasan Pantura Jakarta.

Kata reklamasi berasal dari bahasa Inggris yakni reclaim yang berarti membuat daratan dari laut. Reklamasi adalah suatu usaha mengurug laut untuk pemekaran kota (Zaidiem, 1995). Chapman dalam (Asbullah, 2003), pada umumnya reklamasi sebagai proses untuk membuat lahan agar cocok untuk pemanfaatan tertentu. Tujuan reklamasi pantai dilakukan adalah: 1) memperoleh lahan baru yang dapat mengurangi tekanan atas kebutuhan lahan di bagian kota yang sudah padat; 2) menghidupkan kembali transportasi air sehingga beban transportasi darat berkurang; 3) membuka peluang pembangunan nilai tinggi; 4) meningkatkan pariwisata bahari; 5) meningkatkan pendapatan daerah; 6) meningkatkan pertumbuhan ekonomi masyarakat di sekitar kawasan pantai maupun ekonomi perkotaan; dan 7) meningkatkan sosial ekonomi masyarakat (Suhud, 1998).

Reklamasi merupakan subsistem dari sistem pantai, sedangkan dalam hukum positif di Indonesia pengaturan mengenai reklamasi dapat dilihat dalam UU No. 27 Tahun 2007 tentang Pengelolaan Wilayah Pesisir dan Pulau-Pulau Kecil pasal 1 butir 23 memberikan definisi bahwa reklamasi adalah kegiatan yang dilakukan oleh orang dalam rangka meningkatkan manfaat sumberdaya lahan ditinjau dari sudut lingkungan dan sosial-ekonomi dengan cara pengurugan, pengeringan lahan, atau drainase. Dalam pasal 34 menjelaskan bahwa hanya dapat dilaksanakan jika manfaat sosial dan ekonomi yang diperoleh lebih besar dari biaya sosial dan biaya ekonominya (Indonesia, 2007). Namun demikian, pelaksanaan reklamasi juga wajib menjaga dan memperhatikan beberapa hal seperti: (a) keberlanjutan kehidupan dan penghidupan masyarakat, (b) keseimbangan antara kepentingan pemanfaatan dan pelestarian lingkungan pesisir, serta persyaratan teknis pengambilan, pengerukan, dan penimbunan materil (Rellua, 2013). Reklamasi dapat dilaksanakan jika manfaat sosial dan ekonomi yang diperoleh lebih besar dari biaya sosial dan biaya ekonominya, sesuai Undang-undang No. 27 tahun 2007 pasal 34 (Siswantoro, Pratikto, \& Mustain, 2017).

Dengan mempertimbangkan berbagai hal sebagaimana telah disebutkan sebelumnya, maka dibutuhkan penelitian tentang urgensi dari kebijakan reklamasi Pantai Utara DKI Jakarta. Pemerintah pusat dan pemerintah provinsi DKI Jakarta memiliki kewajiban untuk memberikan kesejahteraan bagi masyarakat luas dalam hal pengembangan tata ruang Pantai Utara DKI Jakarta. Namun, dalam implementasinya, terjadi berbagai permasalahan, termasuk pro dan kontra atas kebijakan reklamasi tersebut.

Reklamasi bukan hanya memberikan dampak positif terhadap sosial dan ekonomi warga sekitar, tetapi juga perlu mengindentifikasi dampak negatif lainnya terhadap lingkungan sekitar, seperti degradasi lingkungan, ketidakstabilan tanah, dan kepunahan ekosistem pesisir pantai, termasuk biota-biota laut yang ada. Selain itu, reklamasi Kawasan Pantai Utara DKI Jakarta syarat dengan pro-kontra dan banyaknya unsur-unsur kepentingan dari pemangku kekuasaan. Atas dasar tersebut, penulis akan lebih fokus membahas dan melihat dari bidang urgensi dari kegiatan reklamasi Pantai Utara DKI Jakarta.

Berdasarkan tinjauan penelitian-penelitian sebelumnya dan pro-kontra yang muncul atas kebijakan reklamasi Kawasan Pantai Utara DKI Jakarta, penulis membuat pertanyaan penelitian sebagai berikut. (a) Bagaimana proses pengambilan kebijakan reklamasi Pantai Utara DKI Jakarta? dan (b) Dampak apa saja yang ditimbulkan dari proyek reklamasi Pantai Utara DKI Jakarta yang sudah berjalan?

\section{METODE}

Dinamika kebijakan Reklamasi Pantai Utara DKI Jakarta mendapat banyak persetujuan serta penolakan dari berbagai kalangan. Penelitian ini bertujuan untuk dapat 
mengetahui bagaimana proses pembahasan atau perancangan kebijakan tersebut disinyalir terkesan banyak tindakan cacat hukum hingga benturan kepentingan. Tak jarang bahwa proses reklamasi ini kawasan pesisir Pantai Utara DKI Jakarta memang banyak pandangan yang tidak setuju terhadap kebijakan ini, namun pada akhirnya tidak dapat dipungkiri bahwa kegiatan reklamasi pantai utara akan memberikan tambahan fungsi lahan dan nilai ekonomi.

Untuk menjelaskan mengenai dinamika dalam pembentukan kebijakan reklamasi pantai utara oleh pemangku kepentingan lainnya yang memiliki power dalam kebijakan tersebut. Sehingga, dengan menjelaskan persoalan mengenai kebijakan reklamasi Pantai Utara Jakarta tersebut, dapat diketahui bagaimana urgensi dari kebijakan tersebut.

Penelitian ini menggunakan model penelitian kualitiatif dengan menggunakan data primer dan sekunder. Data primer diperoleh dari hasil melalui wawancara langsung dengan tokoh masyarakat pemerhati lingkungan, dan observasi ke sekitar proyek reklamasi. Sedangkan data sekunder diperoleh dari literatur (dokumen resmi: UU/Keppres/Perda/Pergub, pernyataan resmi, penelitian ilmiah sebelumnya, media cetak dan online, buku, dan sumber internet) yang membahas tentang reklamasi Pantai Utara DKI Jakarta. Data primer dan sekunder kemudian dianalisis dengan teknik deskriptif kualitatif, yaitu mendeskripsikan teori-teori dan juga penemuan-penemuan terkait serta menganalisis pengaruh teori-teori tersebut dalam penerapan kebijakan reklamasi di Pantai Utara DKI Jakarta, sehingga dapat menjawab bagaimana proses kebijakan dibuat dan dampak proyek reklamasi di Pantai Utara DKI Jakarta.

\section{HASIL DAN PEMBAHASAN}

\section{Kebijakan Reklamasi Pantai Utara DKI Jakarta}

Permasalahan dan tantangan yang dihadapi Provinsi DKI Jakarta sebagai Ibukota Negara meliputi permasalahan dan tantangan yang terkait dengan infrastruktur wilayah, daya dukung lingkungan dan sumber daya alam, ketahanan sosial dan budaya, serta kapasitas dan kualitas pemerintahan, kerjasama regional, dan daya saing ekonomi daerah itu sendiri. Adapun kemudian permasalahan pembangunan daerah Provinsi DKI Jakarta (RPJMD DKI Jakarta 2013-2017, n.d.) adalah:

(a) Sistem Transportasi, yaitu permasalahan kapasitas jalan yang tidak mampu menampung jumlah kendaraan yang ada.

(b) Banjir dan Genangan, yang diakibatkan tingginya curah hujan di hulu dan berkurangnya daerah resapan air di hulu sungai akibat perubahan fungsi lahan yang tidak terkendali.

(c) Perumahan dan Pemukiman, yaitu keterbatasan lahan untuk penyediaan hunian yang layak dan terjangkau bagi seluruh lapisan masyarakat Jakarta.

(d) Ruang Terbuka Hijau, yaitu penyediaan dan penyebaran dan kualitas RTH publik dan privat di seluruh wilayah serta pengembangan tajuk hijau, belum terwujud secara maksimal.

(e) Penataan Ruang, yaitu pemanfaatan ruang kota seringkali melebihi kapasitas daya dukungnya dan tidak sesuai dengan rencana tata ruang yang ada, sehingga mempengaruhi tata ruang kota DKI Jakarta.

Kebijakan terkait reklamasi Pantai Utara DKI Jakarta merupakan sebuah upaya pemerintah agar dapat menyelesaikan permasalahan yang ada di DKI Jakarta terkait dengan menanggulangi bencana banjir, kekurangan lahan, sampai dengan tindakan untuk memperbaiki tata ruang kota. Perkembangan ruang kota tidak terjadi secara abstrak, melainkan dipengaruhi oleh proses dimensi waktu yang cukup lama, dilakukan oleh manusia dan berkaitan erat dengan produk (Zahd, 1999).

Untuk memenuhi tuntutan kebutuhan lahan, trendnya bahwa kota-kota di pesisir pantai cenderung menambah luas lahannya dengan melakukan reklamasi pantai, sehingga 
dapat menambah lahan baru yang kemudian dapat dimaksimalkan untuk upaya memperbaiki permasalahan terkait keterbatasan lahan (Nurmandi, 1999).

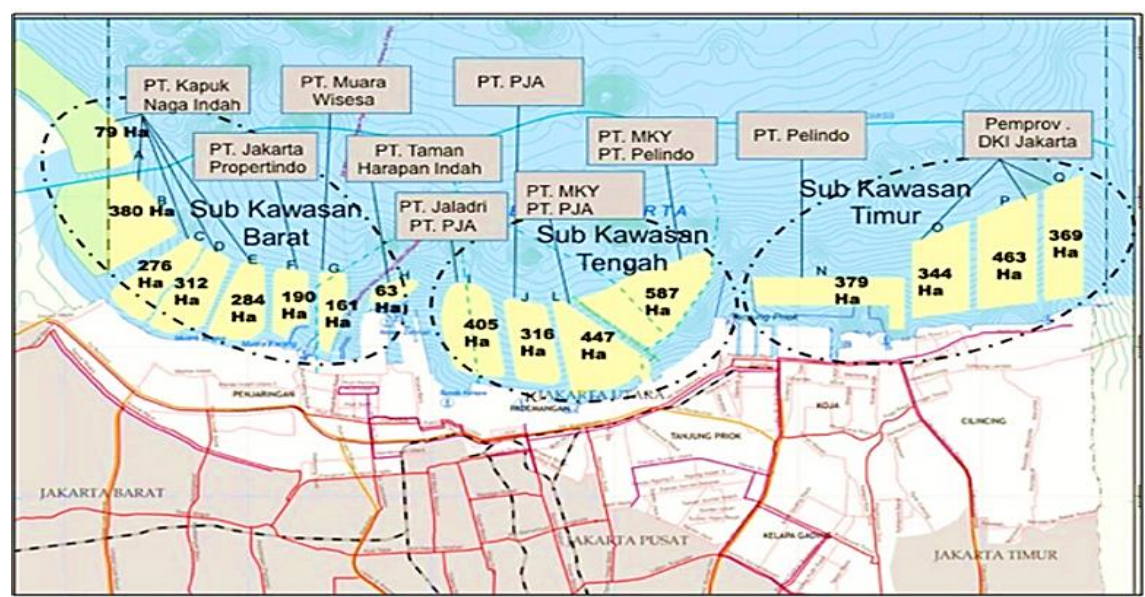

Sumber: Kementrian Lingkungan Hidup dan Kehutanan (KLHK) dalam Mongabay

Gambar 1. Peta Rencana Reklamasi Pantai Utara DKI Jakarta

Pemekaran kota menjadi alasan utama reklamasi sehingga alternatif kebijakan reklamasi pantai dilakukan karena berbagai alasan berkaitan dengan peningkatan jumlah penduduk. Akibat yang ditimbulkan dari pertambahan penduduk secara alami maupun migrasi, dan kesejahteraan penduduk yang miskin mendorong masyarakat yang semula tinggal di tengah kota memilih ke daerah pinggiran atau tempat baru untuk dapat memulai usaha demi meningkatkan kesejahteraannya (DKP, 2001).

Namun kemudian, kebijakan reklamasi Pantai Utara DKI Jakarta memang menimbulkan banyak pro dan kontra dari berbagai kalangan. Perbedaan pandangan mengenai reklamasi tersebut sangat dapat dimengerti. Berbagai peneliti telah membuat kajian-kajian terkait dengan kegiatan reklamasi, dari adanya kecacatan hukum, analisis kajian terkait dampak reklamasi yang ditimbulkan sampai dengan pemanfaatan hasil reklamasi yang hanya menguntungkan pengembang.

Menurut Pemprov DKI Jakarta, reklamasi yang sudah diwacanakan sejak tahun 1985 ini dinilai perlu dilakukan untuk mengatasi terkait permasalahan lingkungan dan lahan di Pantai Utara Jakarta, yang dianggap telah mengalami penurunan manfaat. Kawasan utara Jakarta dianggap memiliki lingkungan buruk akibat permasalahan banjir rob, sampah dan limbah sehingga mempengaruhi pada kualitas kawasan tersebut. Sehingga pada tahun 1995, pemerintah pusat menerbitkan Keppres No. 52 Tahun 1995 tentang Reklamasi Pantai Utara Jakarta. Dalam Keppres tersebut, Gubernur DKI Jakarta memiliki wewenang untuk memberikan izin reklamasi untuk dapat memaksimalkan kawasan yang seyogyanya telah mengalami penurunan kualitas lingkungan (Cahya, 2016).

Kemudian, tujuan dasar dilakukannya reklamasi adalah sebagai langkah pemerintah untuk perlindungan jangka panjang pada wilayah Ibukota dari ancaman banjir sekaligus pengembangan sosial dan ekonomi Jakarta agar dapat lebih memaksimalkan sumber daya yang ada. Jika melihat secara spesifik dari Master Plan Pengembangan Terpadu Pesisir Ibukota Negara (PTPIN) Tahun 2014, terdapat 10 ambisi yang tersemat dalam reklamasi Pantai Utara DKI Jakarta, yaitu: melindungi wilayah pesisir Jakarta dari banjir; menyediakan ruang baru; kota pesisir yang tertata; menciptakan lapangan kerja dan tempat tinggal; 
meningkatkan aksesibilitas antar wilayah yang bebas hambatan; meningkatkan sektor perekonomian kelautan; menyediakan lingkungan hidup yang sehat; menyediaan air baku; model perencanaan wilayah berkelanjutan; dan wilayah yang mencerminkan kebudayaan Indonesia (Ramadhan, Firdaus, Wijaya, \& Muliawan, 2016).

\section{Permasalahan Kebijakan Reklamasi Pantai Utara DKI Jakarta}

Alasan utama reklamasi Pantai Utara Jakarta dimulai tahun 1995, yang memiliki tujuan untuk mencegah pengikisan daratan Jakarta oleh air laut, serta membangun beberapa fasilitas kota lainnya. Bukan hanya itu, reklamasi pantai utara Jakarta juga bertujuan untuk menata kembali dengan cara membangun kawasan pantai dan menjadikan Jakarta sebagai kota pantai (waterfront city) karena ruang Jakarta sudah tidak mungkin diperluas. Terdapat perubahan tata ruang di Perda No. 1 Tahun 2012 Tentang RTRW 2010-2030 menjadi pulaupulau kecil yang terpisah dari daratan.

Namun pada kenyataannya, permasalahan pembangunan reklamasi teluk Jakarta ini sangat kompleks, baik dari segi perizinan, masalah ekonomi, sosial sampai dengan masalah lingkungan. Misalnya dalam masalah perizinan, masih terdapat dua sumber hukum yang bertentangan, yaitu: Keppres No. 52 tahun 1995 sebagai pendukung keberlangsungan proyek reklamasi pantura DKI Jakarta yang bertentangan dengan Perpres No. 54 Tahun 2008 tentang rencana tata ruang Jabodetabekpunjur, yang menyatakan bahwa Keppres No. 52 Tahun 1995 sepanjang berkaitan dengan aspek tata ruang tidak lagi berlaku.

UU No. 27 Tahun 2007 tentang Pengelolaan Wilayah Pesisir dan Pulau-Pulau Kecil juga tidak menjadi acuan Pemprov DKI Jakarta dalam memberikan ijin proyek reklamasi. Terutama Pasal 34 yang menjelaskan bahwa reklamasi wilayah pesisir dan pulau-pulau kecil dalam rangka meningkatkan manfaat dan nilai tambah harus ditinjau dari aspek teknis, lingkungan, dan sosial ekonomi, dan pelaksanaannya harus melibatkan masyarakat sekitar. Dengan merujuk kepada pasal tersebut, pemegang otoritas tidak mentaati pasal tersebut. Dalam hal ini pelaksanaan UU No. 27 Tahun 2007 tidak menjadi acuan dihampir semua proyek reklamasi.

Selanjutnya, kecacatan hukum terkait dalam proyek reklamasi tersebut juga dikemukakan oleh Marthin Hadiwinata, perwakilan dari Koalisi Selamatkan Teluk Jakarta menanggapi Surat Gubernur DKI Jakarta No. 2054/-1.794.2 yang di dalamnya menyebutkan alasan kenapa moratorium harus dicabut. Mereka melihat bahwa surat tersebut secara nyata bertentangan dengan hukum dan mencederai keadilan untuk nelayan secara khusus serta masyarakat pesisir teluk Jakarta pada umumnya. Alasan yang dipergunakan di dalam surat tersebut untuk melanjutkan pembahasan Raperda tentang Rencana Tata Ruang Kawasan Strategis Pantai Utara Jakarta (RTR KS Pantura Jakarta) dan Raperda tentang Rencana Zonasi Wilayah Pesisir dan Pulau Pulau Kecil (RZWP3K) atau disebut sebagai Rapperda Reklamasi. Raperda ini dianggap banyak menutup fakta-fakta yang ada, mulai dari dampak buruk reklamasi terhadap lingkungan hidup, hingga fakta hukum yang menjadi dasar untuk tidak melanjutkan reklamasi (Ambari, 2017).

Kemudian, Koalisi Selamatkan Teluk Jakarta menemukan dan menjelaskan setidaknya 7 alasan yang mendasari keberatan terhadap Surat Gubernur DKI Jakarta No. 2054/-1.794.2 dan meminta DPRD untuk mempertimbangkan menghentikan pembahasan dua Raperda Reklamasi ini (Ambari, 2017), yaitu:

(a) Surat Menko Maritim No. S-78-001/02/MENKO/X/2017 tidak relevan karena tiada kewenangan dari Menko Maritim untuk kemudian menyatakan bahwa reklamasi dapat berlanjut. Surat tersebut tidak berdasarkan adanya kajian ilmiah yang transparan terhadap alasan dicabutnya moratorium reklamasi. Surat tersebut bertentangan dengan rekomendasi dari Kemeko Kemaritiman sendiri di tahun 2016 yang mengatakan bahwa Reklamasi Pulau G dihentikan dan mengevaluasi reklamasi pulau lainnya. 
(b) Putusan Mahkamah Agung No. 92/K/TUN/LH/2017 tidak menghilangkan fakta bahwa masih ada proses pengadilan yang memeriksa gugatan nelayan dan organisasi lingkungan hidup terhadap Gubernur DKI Jakarta yang menerbitkan reklamasi. Setidaknya ada 3 gugatan lingkungan hidup yang sedang berjalan antara nelayan dengan Putusan No. 14 /G/LH/2016/PTUN-JKT), Pulau I (SK Gubernur No. 2485/2015 dan Putusan No. 13/G/2015/PTUN-JKT). Dari tiga gugatan tersebut menunjukkan bahwa proyek reklamasi adalah proyek bermasalah dan seharusnya dihentikan.

(c) Kajian Lingkungan Hidup Strategis (KLHS) Raperda RTR KS Pantura dilakukan secara tertutup dan tidak melibatkan masyarakat. Patut diingat bahwa hanya ada satu kali konsultasi publik yang dilakukan setelah kajian dilakukan dengan undangan disebar (lihat Siaran Pers Koalisi tertanggal 10 Maret 2017). Surat undangan sampai ke peserta yang diundang tidak sampai 24 jam sebelum kegiatan dan tanpa dilampirkan dokumen yang dibahas.

(d) Terkait dengan Keputusan Menteri Lingkungan Hidup dan Kehutanan No. 499/Setjen/Kum.9/9/2017 tertanggal 15 September 2017 dan No. 537/Menlhk/Setjen/Kum.9/10/2017, kedua surat keputusan tersebut menunjukkan lemahnya kedudukan pemerintah di depan perusahaan pengembang. Sejak awal Koalisi Selamatkan Teluk Jakarta meminta adanya pencabutan izin lingkungan semua proyek reklamasi di Teluk Jakarta karena jelas banyak permasalahan mulai tiadanya dasar hukum perencanaan Rencana Zonasi Wilayah Pesisir dan Pulau Pulau Kecil hingga pembuatan AMDAL yang diduga tidak partisipatif, tidak valid, dan cacat substantif karena bertentangan dengan tata ruang (AMDAL Bodong).

(e) Melanjutkan pembahasan raperda RTR KS Pantura dan Raperda RZWP3K diselimuti jual-beli pasal dan kemudian menjadi dasar untuk pemulusan proyek reklamasi berjalan. Terlebih KLHS dari Raperda RZWP3K tidak memiliki kajian lingkungan hidup strategis. Selain itu KLHS juga tidak berdasarkan daya dukung dan daya tampung teluk Jakarta.

(f) Sejak 17 Oktober 2014, menjelang 3 tahun, Pemerintah dan Pemerintah Daerah harusnya mematuhi Undang-Undang No. 32 tahun 2014 tentang Kelautan. Dalam pasal 34 Ayat (1) UU No. 32 Tahun 2014, Pemerintah harus memenuhi mandat adanya Peraturan Pemerintah mengenai Rencana Tata Ruang Laut Nasional, yang menjadi dasar dari setiap perencanaan Tata Ruang dan Rencana Zonasi Wilayah Pesisir dan Pulau-Pulau Kecil. Sehingga jika DPRD DKI Jakarta tetap memaksakan melanjutkan pembahasan Raperda Reklamasi tersebut akan dapat dinyatakan sebagai perbuatan melawan hukum dan undang-undang yang berlaku;

(g) Secara politis, Gubernur Djarot seharusnya menghormati Gubernur terpilih yang memiliki janji untuk menghentikan reklamasi. Jika Raperda RTR KS Pantura dan Raperda RZWP3K dipaksakan lanjut, DPRD hanya akan menambah masalah bagi pemerintah baru. Sehingga sudah seharusnya DPRD DKI Jakarta menolak permintaan Gubernur Djarot.

Selain itu, Tigor Hutapea dari Deputi Hukum dan Kebijakan Koalisi Rakyat untuk Keadilan Perikanan berpendapat bahwa dalam konteks pencabutan Moratorium yang dilakukan oleh Luhut Binsar Panjaitan merupakan sebuah tindakan yang keliru (Hutapea, 2017). Luhut mencabut moratorium proyek reklamasi Teluk Jakarta melalui surat No. S-78001/02/Menko/Maritim/X/2017. Pencabutan tersebut didasari permohonan Djarot Saiful Hidayat Gubernur DKI Jakarta untuk meninjau kembali moratorium reklamasi, karena Luhut memandang bahwa pertimbangan sudah tidak ada permasalahan lagi, baik segi teknis maupun dari segi hukum.

Tigor menambahkan, berbagai peraturan telah secara jelas mengatur proses pelaksanaan reklamasi. UU No. 1 Tahun 2014 yang merubah UU No. 27 Tahun 2007 tentang Pengelolaan Wlayah Pesisir dan Pulau-Pulau Kecil adalah aturan pokok yang mengatur reklamasi di wilayah pesisir dan pulau-pulau kecil, kemudian didukung dengan aturan 
turunan berupa Peraturan Presiden No. 122 Tahun 2012 Tentang Reklamasi, Permen KP No. 34/PERMEN-KP/2014 tentang Perencanaan Pengelolaan Wilayah Pesisir dan Pulau-Pulau Kecil dan Permen KP No. 28 /PERMEN-KP/2014 tentang Perizinan Reklamasi di Wilayah Pesisir dan Pulau-Pulau Kecil.

Berikut ini adalah hasil penjelasan Tigor Hutapea dalam sesi wawancara dengan penulis, sebagai berikut (Hutapea, 2017):

(a) Pertama, terkait ketiadaan peraturan Tata Ruang Wilayah Pesisir dan Pulau-Pulau Kecil. Secara jelas dalam pasal 11 Perpres No. 122 Tahun 2012 tentang Reklamasi, mengatakan setiap pihak yang merencanakan reklamasi wajib memperhatikan Kajian Lingkungan Hidup Strategis (KLHS) dan harus sesuai dengan Peraturan Daerah Zonasi Wilayah Pesisir dan Pulau-Pulau Kecil (Perda RZWP3K). KLHS dan Perda RZWP3K merupakan syarat utama menentukan lokasi reklamasi, melakukan penyusunan Rencana Induk Reklamasi, melakukan studi kelayakan lingkungan dan penyusunan rancangan detail reklamasi. Permen KP No. 34/PERMEN-KP/2014 mengatur Izin Lokasi Reklamasi harus didasarkan kepada Peraturan Daerah RZWP3K. Izin Lokasi pun terbagi atas 2 yaitu: izin lokasi reklamasi dan izin lokasi sumber material reklamasi, artinya daerah yang menjadi lokasi reklamasi dan sumber material harus memiliki Perda RZWP3K. Kita ketahui bahwa hingga saat ini DKI Jakarta belum memiliki Perda RZWP3K yang mengatur secara khusus wilayah pesisir dan pulau-pulau kecil begitu juga wilayah pengambilan pasir reklamasi yang rencana berasal dari wilayah Provinsi Banten yang juga belum memiliki Perda RZWP3K. Walaupun saat ini Perda RZWP3K sedang disusun namun diperlukan konsultasi dan koordinasi ke Kementerian Kelautan dan Perikanan yang sedang menyusun rencana zonasi laut di kawasan strategis nasional Jabodetabekpunjur (Jakarta, Bogor, Depok, Tangerang, Bekasi, Puncak dan Cianjur).

(b) Kedua, adalah masalah ketiadaan rekomendasi dari Kementerian Kelautan dan Perikanan. Walaupun zona 0-12 mil laut pengaturannya menjadi kewenangan Provinsi, namun untuk reklamasi melalui pasal 8 Permen KP No. 17/PERMEN-KP/2013 mengatur proyek-proyek reklamasi dengan lausan di atas 25 (dua puluh lima) hektar wajib mendapatkan rekomendasi menteri kelautan perikanan. Pembangunan tujuh belas pulau reklamasi di teluk Jakarta memiliki luas diatas 25 HA sehingga wajib mendapatkan rekomendasi menteri KKP. Namun hingga saat ini belum ada rekomendasi yang dikeluarkan Kementerian Kelautan Perikanan untuk pembangunan pulau-pulau reklamasi bahkan diberbagai pernyataan media Menteri KKP menunjukan sikap menolak pelaksanaan reklamasi teluk Jakarta. Bahkan Hasil studi Pusat Penelitian Sosial Ekonomi Kelautan dan Perikanan Kementerian Perikanan dan Kelautan RI menjelaskan hilangnya 1 hektar luas wilayah perairan menyebabkan kerugian ekonomi Rp 26. 899.369 pertahun, budidaya kerang hijau Rp 85.599.135 pertahun, luasan tambak perhektar Rp 27.992.942 pertahun dan biaya perbaikan ekosistem mangrove mencapai 28 miliar perbulan selama 10 tahun.

(c) Ketiga, tidak adanya partisipasi publik dan keterbukaan. Sepanjang moratorium berlangsung Menko Maritim tidak melibatkan partisipasi publik khususnya pihak-pihak yang menolak reklamasi, perkembangan informasi pembahasan tidak pernah dibuka. Padahal UU tentang Perlindungan dan Pengelolaan Lingkungan Hidup membuka ruang partisipasi publik dan keterbukaan dokumen-dokumen lingkungan hidup. Pembahasan yang hanya dilakukan instansi kementerian dan pemerintah daerah justru membuat bias keputusan yang dibuat.

Seperti diketahui, bahwa perumusan kebijakan tidak terlepas dari pengaruh kekuatan dan kekuasaan dari korporasi. Karena, jika melihat realitanya bahwa formulasi sebuah kebijakan selalu dicampuri dengan urusan ekonomi. Seperti yang tercermin dalam kebijakan reklamasi Pantura DKI Jakarta, bahwa kebijakan tersebut sudah dapat terlihat adanya peranan dan campur tangan dari aktor pemangku kepentingan. Sehingga kebijakan tersebut tidak lagi dipandang murni 
demi kepentingan masyarakat secara luas, namun hanya bertitik kepada kepentingan korporasi dan segelintir kelompok saja.

\section{Peranan Korporasi dalam Mempengaruhi Kebijakan Reklamasi Pantai Utara DKI Jakarta}

Pembuatan kebijakan dipengaruhi oleh beberapa faktor. Hal penting yang turut diwaspadai dan selanjutnya dapat diantisipasi adalah dalam pembuatan kebijakan sering terjadi kesalahan umum. Faktor-faktor yang mempengaruhi pembuatan kebijakan (Suharno, 2010) adalah: (a) adanya pengaruh tekanan-tekanan dari luar; (b) adanya pengaruh kebiasaan lama; (c) adanya pengaruh sifat-sifat pribadi; (d) adanya pengaruh dari kelompok luar; dan (e) adanya pengaruh keadaan masa lalu. Kebijakan publik merupakan produk politik, sehingga unsur unsur politik akan ikut mewarnai kebijakan yang dihasilkan. Menjadi persoalan jika warna politik itu tidak proporsional, misalnya didominasi oleh warna dan kepentingan tertentu (Rusli, 2013).

Untuk proyek kebijakan reklamasi Pantai Utara DKI Jakarta, pemerintah pusat dan daerah mengajak pengembang, dalam artian korporasi atau swasta untuk terlibat dalam implementasi kebijakan tersebut. Pihak swasta yang terlibat dalam proyek reklamasi Pantai Utara DKI Jakarta sebagai berikut.

Tabel 1. Perusahaan yang Terlibat Reklamasi Pantai Utara DKI Jakarta

\begin{tabular}{llll}
\hline Pulau & Pengembang/Developer & Luas Pulau & Status \\
\hline A & PT Kapuk Naga Indah & $79 \mathrm{Ha}$ & Izin Prinsip \\
B & PT Kapuk Naga Indah & $380 \mathrm{Ha}$ & Izin Prinsip \\
C & PT Kapuk Naga Indah & $279 \mathrm{Ha}$ & Proses Reklamasi \\
D & PT Kapuk Naga Indah & $312 \mathrm{Ha}$ & Proses Reklamasi \\
E & PT Kapuk Naga Indah & $284 \mathrm{Ha}$ & Izin Prinsip \\
F & PT Jakarta Propertindo & $190 \mathrm{Ha}$ & Izin Pelaksanaan \\
G & PT Muara Wisesa Samudra & $161 \mathrm{Ha}$ & Proses Reklamasi \\
H & PT Taman Harapan Indah & $63 \mathrm{Ha}$ & Izin Pelaksanaan \\
I & PT Jaladri Kartika Eka Paksi & $405 \mathrm{Ha}$ & Izin Pelaksanaan \\
J & PT Pembangunan Jaya Ancol & $316 \mathrm{Ha}$ & Izin Prinsip \\
K & PT Pembangunan Jaya Ancol & $32 \mathrm{Ha}$ & Izin Pelaksanaan \\
L & PT Manggala Krida Yudha & $481 \mathrm{Ha}$ & Izin Prinsip \\
M & PT Manggala Krida Yudha & $587 \mathrm{Ha}$ & Izin Prinsip \\
N & PT Pelindo II & $411 \mathrm{Ha}$ & Proses Reklamasi \\
O & Pemprov DKI Jakarta & $344 \mathrm{Ha}$ & Izin Prinsip \\
P & Pemprov DKI Jakarta & $483 \mathrm{Ha}$ & Izin Prinsip \\
Q & Pemprov DKI Jakarta & $369 \mathrm{Ha}$ & Izin Prinsip \\
\hline
\end{tabular}

Sumber: Diolah Penulis, 2018

Namun, dalam realitanya bahwa pengembang telah melakukan tindakan yang merugikan masyarakat secara luas, yaitu mempengaruhi arah kebijakan yang akan dilakukan oleh pemerintah. Pengembang telah melakukan beberapa manuver agar dapat mempengaruhi kebijakan yang dirancang hanya untuk menguntungkan kepentingan ekonominya. KPK (Komisi Pemberantasan Korupsi) telah mendapatkan petunjuk baru dalam pengembangan kasus suap rancangan Perda tentang reklamasi. Dalam kasus ini, KPK telah menetapkan tiga tersangka: Mohammad Sanusi, anggota DPRD DKI Jakarta; Ariesman Widjaja, Presiden Direktur PT Agung Podomoro Land, sebagai pengembang reklamasi; dan Trinanda Prihantoro, anak buah Ariesman. Bukan hanya Podomoro yang terseret, Reklamasi Teluk Jakarta juga menyeret raksasa property lain, yaitu Agung Sedayu Group. Anak usaha Agung Sedayu, PT Kapuk Naga Indah, menjadi pemegang konsesi Pulau C dan Pulau G. Bos Agung Sedayu, Sugianto Kusuma alias Aguan, telah dicegah ke luar negeri (Tempo.co, 2016). 
Kebijakan Basuki Purnama alias Ahok menyangkut kewajiban ekstra pada PT Muara Wisesa Samudera sebagai anak usaha PT Agung Podomoro Land. PT Muara merupakan pemiliki izin reklamasi Pulau G seluas 161 hektare atau dikenal sebagai Pluit City. Perusahaan itu diwajibkan membiayai proyek senilai Rp. 392,6 miliar sebagai kontribusi tambahan sekaligus menjadi syarat memperoleh izin reklamasi pantai (Sudarsono, 2016).

Kemudian, ada tiga kewajiban pengembang yang diatur dalam rancangan tersebut. Pertama, keharusan menyerahkan fasilitas umum dan sosial, seperti jalan dan ruang terbuka hijau. Kedua, kontribusi 5 persen lahan, dan Ketiga, kontribusi tambahan sebesar 15 persen untuk menanggulangi dampak reklamasi tersebut. Pengembang keberatan terhadap kontribusi tambahan 15 persen yang diatur dalam Pasal 110 Rancangan Peraturan Daerah tentang Tata Ruang Kebijakan penerimaan kontribusi tambahan dari pengembang reklamasi berpotensi menyimpang karena tidak memiliki dasar hukum. Ketentuan ini baru diusulkan dalam Raperda tentang Rencana Tata Ruang Pantai Utara DKI Jakarta meminta kontribusi tambahan yang diusulkan Ahok sebesar 15\% dihapus atau paling tidak turun menjadi $5 \%$. KPK menduga proyek kontribusi tambahan itu sebagai barter penerbitan izin pelaksanaan reklamasi Pulau G yang diterbitkan Ahok pada 23 Desember 2014 (Sudarsono, 2016).

Kemudian, hadirnya kasus suap dibalik pembahasan Raperda di DPRD DKI Jakarta merupakan sebuah upaya untuk melenyapkan rumusan 15\% dari Raperda merupakan skenario bersama pengembang dengan pimpinan DPRD. Dua rancangan yang dibahas Dewan bersama pemerintah DKI Jakarta adalah Raperda Rencana Tata Ruang Kawasan Strategis Pantai Utara Jakarta dan Rapeda Zonasi Wilayah Pesisir dan Pulau-Pulau Kecil Jakarta. Kedua peraturan tersebut yang kemudian akan menjadi payung hukum reklamasi 17 pulau di pesisir laut Jakarta.

Seperti yang telah dijelaskan sebelumnya, dapat disimpulkan bahwa kebijakan terkait dengan reklamasi di pantai utara DKI Jakarta syarat dengan kepentingan korporasi. Kasus suap yang dilakukan oleh pengembang merupakan sebuah bukti dari kekuatan korporasi dalam mempengaruhi pasal kontribusi kebijakan reklamasi pantai utara DKI Jakarta yang hanya dapat menguntungkan pihak pengembang. Seharusnya sebagai wakil rakyat, pemerintah pusat atau daerah harus bertindak tegas dan memutuskan sebuah keputusan di atas kepentingan masyarakat, bukan kepentingan pengembang termasuk kepentingan lainnya yang hadir dalam kebijakan tersebut.

\section{Dampak yang Ditimbulkan dari Kegiatan Reklamasi Pantai Utara DKI Jakarta}

Implikasi kebijakan dalam konteks percepatan pembangunan akan memberikan perubahan sosial ekonomi, maupun perubahan daya dukung lingkungan dalam batas tertentu telah terabaikan. Dampak negatif pembangunan untuk mengejar pertumbuhan seringkali dianggap bukan persoalan hari ini, karena baru terjadi beberapa waktu ke depan. Meskipun pada dasarnya bahwa pertumbuhan pembangunan akan mendorong perekonomian menuju batasnya (Suprapto, 2011).

\section{Dampak Negatif Kegiatan Reklamasi Pantai Utara DKI Jakarta}

Persoalan boleh atau tidaknya reklamasi yang dilakukan di Pantai Utara Jakarta adalah persoalan yang seharusnya dibahas sejak 20 tahun yang lalu. Adapun persoalan saat ini adalah bagaimana menyusun Rencana Tata Ruang di DKI Jakarta, termasuk di kawasan reklamasi, yang disepakati oleh pemerintah dan pengembang sebagai dasar pelaksanaan reklamasi. Gap atau perbedaan persepsi antara pengembang (yang menjual lahan dan bangunan) dan pemerintah (memperhatikan batasan-batasan pelaksanaan reklamasi) harus dapat diperkecil melalui perencanaan tata ruang reklamasi. Saat ini Pemerintah Provinsi DKI Jakarta perlu menyusun RZWP3K Provinsi sebagai dasar penataan ruang laut dan Rencana Tata Ruang. 
Tabel 2. Dampak Penting Reklamasi Teluk Jakarta

\begin{tabular}{ll}
\hline No & Dampak Penting \\
\hline 1 & Membutuhkan 45.000.000 m3 pasir/tanah/aggregate \\
& Masalah logistik pengadaan tanah \\
2 & Pemindahan muara sungai ke laut sejauh $3 \mathrm{~km}$ \\
3 & Peningkatan kepadatan lahan yang direklamasi \\
4 & Perubahan hidrologi air permukaan dan air tanah \\
5 & Perubahan morfologis garis pantai \\
6 & Perubahan kedalaman garis pantai \\
7 & Perubahan Wetland Jakarta Utara (Ecosystem Migratory Birds) \\
8 & Relokasi fasilitas pelabuhan dan maritim \\
9 & Relokasi penduduk \\
10 & Perubahan ekosistem estuari Teluk Jakarta \\
\hline
\end{tabular}

Sumber: Coutrier, 1995 (Suryadewi, Edward, \& Setiadi, 1998)

Reklamasi bagaimanapun telitinya direncanakan, tetap akan mengakibatkan perubahan pada kondisi dan ekosistem pesisir, dan juga ekosistem buatan yang mana baru tentunya tidak akan sebaik yang secara alamiah. Secara garis besar, reklamasi pantai memberikan dampak (Yuwono, 2007), antara lain:

Pertama, reklamasi pesisir demi memperoleh lahan lebih luas merupakan kegiatan paling buruk yang mengubah bentang asli pantai dan wilayah pesisir. Perubahan bentang alam ini akan berakibat pula terhadap perubahan akan hidro-oseanografi terutama arus dan gelombang laut yang tentunya akan menjadi ancaman besar bagi beberapa wilayah pesisir kota.

Kedua, hilangnya potensi sumber daya hayati pesisir terutama beberapa biota laut yang selama ini dimanfaatkan oleh masyarakat nelayan, dan dampak selanjutnya adalah kemungkinan berkurangnya hasil tangkapan nelayan. Secara umum ekosistem seperti, terumbu karang, dan lainnya diketahui memiliki fungsi ekologi yang sangat penting. Untuk itu, bila ekosistem pesisir ini rusak maka fungsi-fungsi tersebut di atas akan hilang, apalagi aktifitas seperti alih fungsi suatu wilayah pesisir, dimana secara fisik akan dapat mengalami tekanan yang sangat besar dan dampaknya akan semakin luas dan kompleks pula.

Ketiga, kemungkinan besar terjadi perubahan dan perpindahan suplai sedimen yang sebelumnya tertampung pada wilayah reklamasi. Pengerukan dan juga penimbunan dalam proses reklamasi pantai dapat menyebabkan perubahan arus laut sekitarnya yang selanjutnya akan mengubah pola sedimentasi.

Keempat, reklamasi berdampak terhadap rusaknya ekosistem mangrove dan juga terumbu karang, yang selanjutnya akan mengakibatkan penurunan kualitas lingkungan sumber daya ikan serta erosi pantai.

Beberapa pakar lingkungan lainnya mengungkapkan dampak negatif kegiatan reklamasi, seperti meningkatnya tekanan terhadap keanekaragaman hayati dan sumberdaya alam (Widodo, 2005), reklamasi yang akan memusnahkan ekosistem alami yang terkena dampak dari kegiatan reklamasi (Suryadewi et al., 1998), reklamasi adalah kegiatan buruk yang mengubah bentang asli pantai dan pesisir yang menghilangkan potensi sumber daya hayati pesisir, mengakibatkan perubahan dan perpindahan suplai sedimen yang sebelumnya tertampung pada wilayah reklamasi, serta merusak ekosistem mangrove dan karang (Huda, 2013).

Dapat dipahami secara jelas bahwa kemudian kegiatan reklamasi akan memberikan dampak yang buruk terhadap lingkungan. Berbagai disiplin ilmu dan penelitian telah melakukan kajian terhadap dampak kegiatan reklamasi. Sehingga pemerintah harus 
bertindak bijaksana dalam merumuskan sebuah kebijakan, agar dapat meminimalisir dampak reklamasi terhadap lingkungan.

Beberapa persoalan teknis yang berpotensi muncul akibat dari pelaksanaan reklamasi tersebut (Wurjanto, 2016) adalah:

(a) Potensi kenaikan muka air di sekitar muara, antara pantai Jakarta saat ini dengan pulaupulau reklamasi.

(b) Sedimentasi dari 13 sungai yang bermuara di teluk Jakarta. Proses sedimentasi ini akan berlangsung terus menerus menghasilkan endapan di sekitar pantai dan pulau reklamasi sehingga harus ditanggulangi dengan pemantauan sedimen dan pengelolaan/pemindahan sedimen secara terus menerus dan berkala.

(c) Penurunan kualitas air selama masa konstruksi pulau reklamasi. Penurunan ini ditunjukkan dengan kekeruhan air akibat sirkulasi air yang terganggu dan sedimentasi.

Dengan demikian, dapat dipahami bahwa sebetulnya kegiatan reklamasi akan memberikan dampak yang buruk terhadap lingkungan. Seringkali, para pemangku kekuasaan hanya berfokus kepada nilai ekonomi yang akan mereka dapatkan. Tanpa pernah memikirkan bagaimana dampak yang akan ditimbulkan jika kegiatan reklamasi terus dilaksanakan.

Dalam analisis ketataairan, penting untuk mensimulasikan berapa jarak minimal antara pulau buatan hasil reklamasi dan pulau utama, agar arus yang terjadi diantaranya tidak menyebabkan perubahan ekologi dan tidak menimbulkan perubahan arus yang membahayakan (Indratmo, 2016).

Persoalan lainnya adalah pengaruh land subsidence, kenaikan muka air laut, dan hambatan aliran yang menaikkan muka air sungai di muara jika pulau-pulau baru tersebut terlalu dekat muara sungai, berpotensi meningkatkan bahaya banjir di pantai Jakarta. Saat ini penanganan banjir di Jakarta Utara sangat tergantung kepada sistem pompa/polder karena muka air laut lebih tinggi dari muka lahannya. Beberapa catatan reklamasi Pantai Utara Jakarta ditinjau dari aspek tata kelola air diantaranya adalah aliran 13 sungai di Provinsi Jakarta berpotensi terhambat aliran disebelah muaranya jika jarak pulau buatan dengan muara sungai terlalu dekat. Dampak yang terjadi adalah kenaikan muka air sungai di muara, yang berarti pelambatan aliran dan otomatis terjadi proses sedimentasi yang lebih parah di muara.

Kedua, dengan adanya kegiatan reklamasi tersebut, sirkulasi air di teluk Jakarta dipastikan akan berubah dengan kehadiran pulau-pulau tersebut. Dibutuhkan untuk dilakukan simulasi berbagai bentuk, ukuran dan lokasi (tempat) pulau-pulau buatan tersebut agar sirkulasi aliran tetap menjamin ekologi laut dan menekan peningkatan sedimentasi diantara pulau terbangun dan pulau besar.

Ketiga, dengan terbangunnya pulau-pulau reklamasi akan menimbulkan penghalangan masyarakat pengguna transportasi air dan nelayan untuk shortcut ke laut lepas. Dibutuhkan adanya kajian sosial alur-alur laut tradisional sehingga mereka tidak terugikan (jangkauan lebih jauh, kualitas air menurun).

Dengan melihat hasil berbagai kajian dampak lingkungan pada kegiatan reklamasi pantai utara DKI Jakarta, dapat terlihat jelas bagaimana proyek kegiatan reklamasi tersebut akan merusak ekosistem pantai yang ada, serta memberikan dampak buruk terhadap lingkungan secara umum.

Hal tersebut berbanding terbalik dengan hasil kajian yang dilakukan oleh Mentri Koordinator Bidang Kemaritiman yang berpendapat bahwa kegiatan reklamasi tidak akan merusak ekosistem pantai dan tidak memberikan dampak yang buruk terhadap lingkungan. Karena, Luhut Binsar dan Ridwan Djamaluddin dari Kementerian Koordinator Kemaritiman mengatakan bahwa regulasi sudah dilakukan dengan peraturan yang ada, semuanya tidak ada kesalahan. Dalam aspek lingkungan, bagi komisi AMDAL sudah tidak ada yang dimasalahkan (Fikri, 2017). 
Dengan demikian, kita dapat memahami bagaimana adanya perbedaan persepsi dari hasil kajian terkait dengan kegiatan reklamasi Pantai Utara DKI Jakarta antara Kemenko Kemaritiman dengan para peneliti lainnya. Karena memang pada realitanya bahwa hasil kajian yang dilakukan oleh Kemenko bidang Kemaritiman tidak pernah diluncurkan ke publik. Sehingga, tidak dapat mengetahui apakah kemudian kementrian terkait telah melakukan kajian atau tidak, atas hal tersebut tidak dapat diketahui bagaimana hasil kajiannya.

\section{Dampak Positif Kegiatan Reklamasi Pantai Utara DKI Jakarta}

Dampak positif kegiatan reklamasi, antara lain peningkatan kualitas dan nilai ekonomi pada kawasan pesisir, mengurangi lahan yang dianggap kurang produktif, penambahan pada fungsi wilayah, perlindungan pantai dari ancaman erosi, peningkatan kondisi habitat perairan, perbaikan rejim hidraulik kawasan pantai, dan yang terpenting adalah penyerapan tenaga kerja bagi masyarakat sekitar.

Hasil wawancara dengan Ruchyat Deni Djakapermana, Sekretaris Direktorat Jenderal Penataan Ruang, Kementerian Pekerjaan Umum, reklamasi banyak memberikan keuntungan dalam mengembangkan wilayah. Dalam hal proyek reklamasi ini memberikan pilihan penyediaan lahan untuk pemekaran wilayah, penataan daerah pantai, menciptakan alternatif kegiatan dan pengembangan wisata bahari. Pulau hasil reklamasi dapat menahan gelombang pasang yang mengikis pantai, Selain itu juga dapat menjadi semacam bendungan untuk menahan banjir rob di daratan. Reklamasi dapat memberikan manfaat ekonomis, sekaligus memberikan nilai tambah pada pelestarian lingkungan (Djakapermana, 2017).

Selain itu, manfaat proyek reklamasi Pantai Utara DKI Jakarta (Aprillah, 2018), sebagai berikut:

(a) Dapat memberikan tambahan daratan buatan hasil pengurugan pantai sehingga dapat dimanfaatkan untuk bermacam kebutuhan.

(b) Daerah yang dilakukan reklamasi menjadi aman terhadap erosi karena konstruksi pengaman sudah disiapkan sekuat mungkin untuk dapat menahan gempuran ombak laut.

(c) Daerah yang ketinggianya dibawah permukaan air laut bisa aman terhadap banjir apabila dibuat tembok penahan air laut di sepanjang pantai.

(d) Tata lingkungan yang bagus dengan perletakan taman sesuai perencanaan, sehingga dapat berfungsi sebagai area rekreasi yang sangat memikat pengunjung.

Dengan penjelasan di atas, dapat dipahami bahwa sekalipun reklamasi memberikan dampak yang buruk terhadap lingkungan, namun kemudian proyek reklamasi setidaknya membawa kebaikan dalam hal pemanfaatan ekonomi, dan memaksimalkan fungsi lahan itu sendiri. Namun kemudian, pemerintah harus bertindak secara adil dan bijaksana dalam mempertimbangkan dampak positif dan negatif dari kebijakan reklamasi Pantai Utara DKI Jakarta. Sehingga, dalam hal memutuskan sebuah pilihan atau kebijakan pemerintah pusat ataupun daerah harus mempertimbangkan konsekuensi atas pengambilan atau pemutusan sebuah kebijakan.

\section{KESIMPULAN}

Kebijakan reklamasi Pantai Utara DKI Jakarta diawali dengan Keppres No. 52 Tahun 1995 tentang Reklamasi Pantai Utara Jakarta, yang bertujuan untuk mencegah pengikisan daratan Jakarta oleh air laut, serta membangun beberapa fasilitas kota lainnya. Namun, kegiatan reklamasi teluk Jakarta ini sangat kompleks, baik dari segi perizinan, masalah ekonomi, sosial, sampai dengan masalah lingkungan. Misalnya masalah perizinan, terdapat dua sumber hukum yang bertentangan, yaitu Keppres No. 52 tahun 1995 sebagai pendukung keberlangsungan proyek reklamasi Pantai Utara DKI Jakarta yang bertentangan dengan 
Perpres No. 54 Tahun 2008 tentang Rencana Tata Ruang Jabodetabekpunjur, yang menyatakan bahwa Keppres No. 52 Tahun 1995 sepanjang berkaitan dengan aspek tata ruang tidak lagi berlaku.

Selain itu, dalam pemberian ijin reklamasi kepada pihak swasta, Pemprov DKI Jakarta tidak mengacu kepada UU No. 1 Tahun 2014 (sebelumnya UU No. 27 Tahun 2007) tentang Pengelolaan Wilayah Pesisir dan Pulau-Pulau Kecil, dimana sebelum proyek reklamasi dilaksanakan, seharusnya terlebih dahulu melakukan peninjauan dari aspek teknis, lingkungan, dan sosial ekonomi, dan pelaksanaannya harus melibatkan masyarakat sekitar. Kenyataaanya, kegiatan reklamasi berjalan terlebih dahulu namun kajian kelayakan dan dampak lingkungan belum dilakukan. Protes dari berbagai kalangan masyarakat mengakibatkan proyek reklamasi dimoratorium melalui putusan pengadilan, hingga adanya Perda baru sebagai payung hukum reklamasi. Untuk memenuhi payung hukum reklamasi, DPRD DKI Jakarta membuat rancangan kebijakan reklamasi. Namun, dalam proses penyusunan rancangan Perda reklamasi, pihak pengembang melakukan beberapa manuver untuk mempengaruhi kebijakan yang dirancang agar menguntungkan kepentingan mereka. KPK telah menetapkan tiga orang tersangka suap atas rancangan Perda reklamasi, yaitu satu anggota DPRD DKI Jakarta dan dua dari pihak pengembang.

Tidak dapat dupungkiri, kebijakan reklamasi Pantai Utara DKI Jakarta menimbulkan dampak negatif dan positif. Beberapa pakar lingkungan mengungkapkan dampak negatif kegiatan reklamasi, seperti meningkatnya tekanan terhadap keanekaragaman hayati dan sumberdaya alam, merusak ekosistem mangrove dan karang, meningkatkan permukaan air di muara, penimbunan sedimen lumpur di muara yang mengakibatkan penyumbatan aliran sungai, mengganggu penghidupan nelayan sekitar, dan lainnya.

Sekalipun reklamasi memberikan dampak yang buruk terhadap lingkungan, namun kemudian proyek reklamasi setidaknya membawa kebaikan dalam hal pemanfaatan ekonomi, seperti bertambahnya daratan Jakarta, merubah lahan menjadi lebih produktif, serta menambah lahan penyerapan tenaga kerja bagi masyarakat sekitar.

\section{REFERENSI}

Adisasmita, R. (2014). Pertumbuhan Wilayah dan Wilayah Pertumbuhan. Jakarta: Graha Ilmu.

Ambari, M. (2017). http://www.mongabay.co.id.

Aprillah. (2018). Dampak Reklamasi. Retrieved February 2, 2018, from https://www.kompasiana.com/aprillah/positif-dan-negatif-reklamasi-teluk-pantai-jakarta-bagimasyarakat-pemerintah-dan-swasta_5739a54ef29673f8072577ce

Asbullah, R. (2003). Hubungan Reklamasi Pantai dengan Komponen Perkembangan Kawasan. Yogyakarta: Prodi MKPD-Pascasarjana UGM.

Cahya, K. D. (2016). Polemik Reklamasi Teluk Jakarta. Retrieved February 2, 2018, from https://megapolitan.kompas.com/read/2016/12/15/11462921/kaleidoskop.2016.polemik.reklamasi.d i.teluk.jakarta?page=all

Djakapermana, R. D. (2017). Wawancara tentang Dampak Reklamasi. Jakarta: Sekretaris Direktorat Jenderal Penataan Ruang, Kementerian Pekerjaan Umum.

DKP. (2001). Pedoman Umum Pengelolaan Pulau-pulau Kecil yang Berkelanjutan dan Berbasis Masyarakat. Jakarta: Departemen Kelautan dan Perikanan.

Fikri, A. (2017, November 3). Reklamasi Jakarta, Menteri Luhut: Saya Cium Tangan Kalau Salah. Tempo.Co. Retrieved from https://bisnis.tempo.co/read/1030569/reklamasi-jakarta-menteri-luhut-saya-ciumtangan-kalau-salah

Fischer, F., Miller, G. J., \& Sidney, M. S. (2007). Handbook of Public Policy. Boca Raton: CRC Press.

Howlett , Michael; Ramesh, M. (1995). Studying Public Policy: Policy Cycles and Policy Subsystems (3rd ed.). New York: Oxford University Press.

Huda, M. C. (2013). Pengaturan Perizinan Reklamasi Pantai Terhadap Perlindungan Lingkungan Hidup. Perspektif, 18(2), 126-135.

Hutapea, T. (2017). Wawancara Masalah Reklamasi Pantai Utara DKI Jakarta. Jakarta. 
Indonesia. UU Pengelolaan Wilayah Pesisir dan Pulau-Pulau Kecil (2007). https://doi.org/10.1017/CBO9781107415324.004

Indratmo, S. (2016). Pandangan Forum Guru Besar Institut Teknologi Bandung Terhadap Reklamasi Pantai Utara Provinsi Dki Jakarta. Pandangan Forum Guru Besar ITB Terhadap Reklamasi Pantai Utara DKI Jakarta, 15.

Kuncoro, M. (2012). Perencanaan Daerah: Bagaimana Membangun Ekonomi Lokal, Kota, dan Kawasan. Jakarta: Salemba Empat.

Muchsin, H., \& Putra, F. (2002). Hukum dan Kebijakan Publik: Analisis Atas Praktik Hukum dan Kebijakan Publik dalam Pembangunan Sektor Perekonomian di Indonesia. Surabaya: Averoes Press.

Nurani, F. (2017). Buruh Migran Perempuan- Afirmasi Kebijakan Bagi Kaum Marginal. Malang: UB Press.

Nurmandi, A. (1999). Manajemen Perkotaan: aktor, organisasi, pengelolaan daerah perkotaan dan metropolitan di Indonesia. Yogyakarta: Lingkar Bangsa.

Perda DKI Jakarta. Perda No. 1 Tahun 2009 tentang Rencana Pembangunan Jangka Menengah Daerah Tahun 2007-2012 (2009).

Putra, F. (2005). Kebijakan Tidak Untuk Publik. Yogyakarta: Resist Book.

Ramadhan, A., Firdaus, M., Wijaya, R., \& Muliawan, I. (2016). Economic Loss of Fisher and Fish Farmer Due to Reclamation of Jakarta Bay. Sosek KP, 11(1), 1-11.

Rellua, O. (2013). Proses Perizinan Dan Dampak Lingkungan Terhadap Kegiatan Reklamasi Pantai. Lex Administratum, Vol.I/No.2/Apr-Jun/2013 PROSES, (2), 163.

RPJMD DKI Jakarta 2013-2017. (n.d.). Jakarta 2017.

Rusli, B. (2013). Kebijakan Publik: Membangun Pelayanan Publik yang Responsif. Bandung: Hakim Publishing.

Siswantoro, D. G., Pratikto, W. A., \& Mustain, M. (2017). Valuasi Sumber Daya Kelautan Pada Rencana Reklamasi Untuk Pengembangan Bandara Juanda Di Pesisir Pantai Kabupaten Sidoarjo, 03(01).

Sudarsono, G. (2016, April 21). Heboh Kontribusi Reklamasi Tiga Skenario Nasib Ahok. Tempo.Co. Retrieved from https://indonesiana.tempo.co/read/74811/2016/05/21/gendursudarsono/heboh-kontribusireklamasi-tiga-skenario-nasib-ahok

Suharno. (2010). Dasar-dasar Kebijakan Publik (Kajian Proses dan Analisis Kebijakan). Yogyakarta: UNY Press.

Suhud, A. R. (1998). Penanggulangan Reklamasi yang Telah Berjalan, dalam Bengen. D.G dan Amiruddin (Eds). In Konperensi 8 Nasional Pengelolaan Sumberdaya Pesisir dan Lautan Indonesia (pp. C113-119). PKSPL IPB-CRC. University of Rhode Island.

Suprapto. (2011). Statistik Pemodelan Bencana Banjir Indonesia (Kejadian 2002-2010). Jurnal Penanggulangan Bencana, 2(2), 34-77.

Suryadewi, I. M., Edward, \& Setiadi, A. (1998). Masalah Reklamasi Teluk Jakarta Ditinjau dari Aspek Psikologi Lingkungan. Jurnal Lingkungan Dan Pembangunan, 18(2), 145-161.

Tempo.co. (2016, April 3). KPK: Banyak Pihak Terlibat Suap Reklamasi. Tempo.Co. Retrieved from https://m.tempo.co/read/news/2016/04/03/063759380/kpk-banyak-pihak-terlibat-suap-reklamasi

Widodo, L. (2005). Kecenderungan reklamasi wilayah pantai dengan pendekatan model dinamik. Jurnal Teknologi Lingkungan, 6(1), 330-338.

Wurjanto, A. (2016). Pandangan Forum Guru Besar Institut Teknologi Bandung terhadap Reklamasi Pantai Utara Provinsi DKI Jakarta. Bandung.

Yuwono, N. (2007). Materi Bahasan Reklamasi. In Lokakarya Nasional Pengelolaan Jasa Kemaritiman dan Kelautan. Jakarta: Departemen Kelautan dan Perikanan.

Zahd, M. (1999). Perancangan Kota Secara Terpadu - Teori Perancangan Kota dan Penerapannya. Yogyakarta: Kanisius.

Zaidiem, M. F. (1995). Reklamasi Jakarta Lautku Sayang Lautku Hilang, Mengangkat Masalah Lingkungan ke Media Massa. Jakarta: Yayasan Obor. 